\title{
Etiologi Demam Neutropenia pada Anak dengan Keganasan dan Penggunaan Skor Klasifikasi Rondinelli
}

\author{
Adrieanta, Endang Windiastuti, Setyo Handryastuti \\ Departemen Ilmu Kesehatan Anak Fakultas Kedokteran Ubiversitas Indonesia/Rumah Sakit Dr. Cipto \\ Mangungkusumo, Jakarta
}

\begin{abstract}
Latar belakang. Pasien anak dengan keganasan dapat mengalami episode demam neutropenia. Pada demam neutropenia, di tiap pusat pelayanan kesehatan, etiologi bakterimia berbeda dan berubah secara periodik. Antibiotik empiris diberikan pada pasien demam neutropenia berdasarkan klasifikasinya. Skor Rondinelli untuk menentukan klasifikasi pasien demam neutropenia menjadi risiko rendah dan risiko tinggi.

Tujuan. Mengetahui karakteristik etiologi dan perjalanan klinis demam neutropenia pada anak dengan keganasan yang dirawat inap di Departemen Ilmu Kesehatan Anak RSCM.

Metode. Penelitian ini adalah deskriptif retrospektif. Sampel diambil dari data sekunder berupa rekam medis pasien anak dengan keganasan yang mengalami demam neutropenia yang menjalani rawat inap di bangsal Departemen IKA FKUI/RSCM mulai bulan Januari 2010 sampai dengan September 2013.

Hasil. Penelitian dilakukan pada 86 pasien anak yang mengalami 96 episode demam neutropenia yang memenuhi kriteria inklusi dan eksklusi. Prevalensi bakterimia pada episode demam neutropenia dengan keganasan 17\%. Proporsi kuman penyebab terbanyak bakterimia adalah Staphylococcus sp (25\%), Pseudomonas aeruginosa (25\%), Klebsiella pneumonia (19\%), dan Escherichia coli (13\%). Penelitian ini mendapatkan $40 \%$ luaran sembuh, $49 \%$ luaran tidak sembuh, dan $6 \%$ meninggal dunia. Berdasarkan skor Rondinelli, episode demam neutropenia risiko rendah yang memiliki luaran sembuh didapatkan 30 (61\%) dan risiko tinggi $13(28 \%)$.

Kesimpulan. Sebagian besar hasil kultur darah pada demam neutropenia adalah steril. Penyebab terbanyak bakterimia adalah kuman Gram negatif. Demam neutropenia memiliki morbiditas yang tinggi. Skor Rondinelli dapat digunakan untuk melakukan klasifikasi demam neutropenia pada anak dengan keganasan. Sari Pediatri 2014;16(4):229-35.
\end{abstract}

Kata kunci: demam neutropenia, etiologi bakterimia, perjalanan klinis, skor Rondinelli

\section{Alamat korespondensi:}

Dr. Adrieanta, Sp.A. Rumah Sakit. Karya Medika IV. Jl. Raya Narogong KM II Pangkalan 1A, Bekasi, Jawa Barat. E-mail: adrieanta@gmail.com

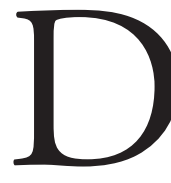

emam neutropenia adalah apabila suhu aksila $>38^{\circ} \mathrm{C}$ yang menetap lebih dari dua jam atau suhu aksila $>39^{\circ} \mathrm{C}$ pada satu kali pengukuran dengan neutrofil 
$<1000 /$ uL. ${ }^{1,2}$ Keadaan neutropenia merupakan faktor risiko untuk terjadinya infeksi bakteri dan jamur yang serius. ${ }^{1}$ Pada anak dengan penyakit keganasan, demam neutropenia bisa disebabkan adanya infeksi atau faktor non infeksi.

Pada pasien demam neutropenia, terapi antibiotik empiris terbukti dapat menurunkan angka morbiditas dan mortalitas. Pemilihan antibiotik sebagai terapi empiris seharusnya berdasarkan informasi berbasis bukti yang sesuai dengan daerah setempat. ${ }^{3}$ Spektrum bakteri penyebab demam neutropenia berubah secara periodik. Spektrum bakteri juga dapat berbeda pada masing-masing pusat pelayanan kesehatan. Penggunaan antibiotik profilaksis, jenis antibiotik yang digunakan pada terapi empiris dan penggunaan kateter, merupakan faktor utama yang memengaruhi variasi spektrum bakteri. ${ }^{4} \mathrm{Hal}$ ini menuntut pembaruan data dasar mengenai kuman penyebab demam neutropenia secara berkala. ${ }^{5}$

Pengklasifikasian pasien demam neutropenia menjadi risiko rendah dan tinggi merupakan strategi yang baik untuk meningkatkan efektivitas terapi dan membantu menentukan jenis antibiotik serta memperkirakan luaran pasien. ${ }^{6}$ Rondinelli $\mathrm{dkk}^{7}$ mengusulkan suatu sistem skoring untuk mengelompokkan pasien demam neutropenia ke dalam risiko rendah, sedang, atau risiko tinggi. Skor Rondinelli mengklasifikasikan pasien anak dengan keganasan yang mengalami demam neutropenia menggunakan parameter klinis pada saat awal masuk

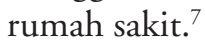

Hidayat $^{7}$ melakukan uji diagnostik untuk validasi skoring Rondinelli. Hasil penelitian menyimpulkan sistem skoring Rondinelli merupakan instrumen yang cukup baik untuk mendeteksi komplikasi infeksi berat pada pasien demam neutropenia. Sensitivitas, spesifisitas, nilai duga positif, nilai duga negatif, rasio kemungkinan positif, dan rasio kemungkinan negatif skoring Rondinelli untuk mendeteksi komplikasi infeksi berat pada pasien LLA-L1 dengan demam neutropenia selama pemberian kemoterapi fase induksi berturut-turut adalah $66,7 \% ; 90,5 \% ; 75 \% ; 86,3 \%$; 6,94; dan 0,36.

Penelitian ini bertujuan untuk mengetahui karakterisitik etiologi bakteriemia dan infeksi saluran kemih serta mengetahui gambaran perjalanan klinis dan luaran berdasar skor Rondinelli pada demam neutropenia pada anak dengan keganasan yang dirawat inap di ruang perawatan anak RSCM.

\section{Metode}

Penelitian deskriptif retrospektif dilakukan di bangsal perawatan anak RSCM Jakarta. Populasi terjangkau adalah semua pasien anak dengan keganasan yang menderita demam neutropenia. Sampel penelitian adalah semua anak pada populasi terjangkau dan memenuhi kriteria inklusi, yaitu pasien anak dengan diagnosis keganasan yang mengalami demam neutropenia. Kriteria eksklusi adalah pasien dengan rekam medis yang tidak lengkap. Sampel diambil secara retrospektif dari data sekunder, berupa rekam medis pasien anak dengan keganasan dan demam neutropenia yang menjalani rawat inap di bangsal anak RSCM periode 2010-2013. Pasien dikatakan risiko rendah apabila total skor $<5,5$, risiko sedang apabila skor 5,5 sampai 9, sedangkan lebih dari 9 dikatakan risiko tinggi. ${ }^{7}$ Pengolahan data dilakukan dengan program SPSS versi 17.0.

\section{Hasil}

Terdapat 86 pasien dengan 96 episode demam. Subjek penelitian berjenis kelamin laki-laki lebih banyak dibanding perempuan dengan rasio 1,4:1. Berdasarkan skor Rondinelli, 50 (52\%) episode demam neutropenia diklasifikasikan sebagai risiko rendah. Telah dilakukan kultur darah dari 96 episode demam neutropenia. Enambelas (17\%) spesimen tumbuh kuman dalam media biakan. Sebagian besar kuman termasuk Gram negatif 11 (69\%). Staphylococcus sp dan Pseudomonas aeruginosa merupakan kuman tersering

Tabel 1. Sistem skoring Rondinelli

\begin{tabular}{lc}
\hline Karakteristik pasien & Skor \\
\hline Usia $\leq 5$ tahun & 1 \\
Usia $>5$ tahun & 0 \\
Kateter vena sentral & 2 \\
Tanpa kateter vena sentral & 0 \\
Fokus infeksi & 4,5 \\
Tanpa fokus infeksi & 0 \\
Demam $\geq 38,5^{\circ} \mathrm{C}$ & 1 \\
Demam $<38,5^{\circ} \mathrm{C}$ & 0 \\
Hemoglobin $\leq 7 \mathrm{~g} / \mathrm{dL}$ & 1 \\
Hemoglobin $>7 \mathrm{~g} / \mathrm{dL}$ & 0 \\
ISPA atas & 2,5 \\
Tanpa ISPA atas & 0 \\
\hline
\end{tabular}


Tabel 2. Karakteristik subjek penelitian $(n=86)$

\begin{tabular}{lcc}
\hline Karakteristik & Jumlah & Persentase(\%) \\
\hline Jenis kelamin & & \\
$\quad$ Laki-laki & 50 & 58 \\
$\quad$ Perempuan & 36 & 41 \\
Jumlah episode per subjek & & \\
1x & 78 & 91 \\
2x & 7 & 8 \\
$3 \mathrm{x}$ & 0 & 0 \\
4x & 1 & 1 \\
Diagnosis utama & & \\
LLA & 45 & 52 \\
LMA & 30 & 36 \\
Neuroblastoma & 4 & 5 \\
LMNH & 2 & 2 \\
Karsinoma nasofaring & 2 & 2 \\
LMK & 1 & 1 \\
Osteosarkoma & 1 & 1 \\
Retinoblastoma & 1 & 1 \\
\hline
\end{tabular}

Tabel 3. Karakteristik episode demam neutropenia berdasarkan skor Rondinelli ( $\mathrm{n}=96)$

\begin{tabular}{lcc}
\hline Karakteristik & Jumlah & Persentase(\%) \\
\hline Kelompok usia (tahun) & & \\
$\quad \leq 5$ & 36 & 38 \\
$\quad>5$ & 60 & 62 \\
Kateter vena sentral & & \\
$\quad$ Ya & 0 & 0 \\
$\quad$ Tidak & 96 & 100 \\
Fokus infeksi & & \\
$\quad$ Diketahui & 51 & 53 \\
$\quad$ Tidak jelas & 45 & 47 \\
Demam $\left({ }^{\circ} \mathrm{C}\right)$ & & \\
$\quad \geq 38,5$ & 61 & 64 \\
$\quad<38$ & 35 & 36 \\
Hemoglobin (g/dL) & & \\
$\quad \leq 7$ & 35 & 37 \\
$\quad>7$ & 61 & 63 \\
ISPA atas & & \\
$\quad$ Ya & 14 & 15 \\
$\quad$ Tidak & 82 & 85 \\
Skor Rondinelli & & \\
$\quad$ Rendah & 50 & 52 \\
$\quad$ Tinggi & 46 & 48 \\
\hline
\end{tabular}

Tabel. 4. Hasil kultur darah dan urin berdasarkan skor Rondinelli ( $\mathrm{n}=96)$

\begin{tabular}{|c|c|c|c|}
\hline \multirow[t]{2}{*}{ Hasil kultur } & \multicolumn{2}{|c|}{ Skor Rondinelli } & \multirow{2}{*}{ Jumlah } \\
\hline & Risiko rendah & Risiko tinggi & \\
\hline \multicolumn{4}{|l|}{ Darah } \\
\hline Steril & 43 & 37 & 80 \\
\hline Escherichia coli & 1 & 1 & 2 \\
\hline Acinetobacter sp & 1 & 0 & 1 \\
\hline Staphylococcus sp & 1 & 3 & 4 \\
\hline Staphylococcus epidermidis (MRSE) & 1 & 0 & 1 \\
\hline Klebsiella pneumoniae & 1 & 2 & 3 \\
\hline Pseudomonas aeruginosa & 2 & 2 & 4 \\
\hline Enterobacter cloaca & 0 & 1 & 1 \\
\hline Total & 50 & 46 & 96 \\
\hline \multicolumn{4}{|l|}{ Urin } \\
\hline Steril & 29 & 40 & 69 \\
\hline Escherichia coli & 7 & 2 & 9 \\
\hline Acinetobakter sp & 5 & 1 & 6 \\
\hline Enterococcus sp & 4 & 1 & 5 \\
\hline Staphylococcus sp & 1 & 0 & 1 \\
\hline Streptococcus alpha hemoliticus & 3 & 0 & 3 \\
\hline Klebsiella pneumoniae & 0 & 1 & 1 \\
\hline Pseudomonas aeruginosa & 0 & 1 & 1 \\
\hline Proteus vulgaris & 1 & 0 & 1 \\
\hline Total & 50 & 46 & 96 \\
\hline
\end{tabular}

Sari Pediatri, Vol. 16, No. 4, Desember 2014 
yang ditemukan (50\%). Hasil tes kepekaan kuman pada kultur darah tertera pada Gambar 1 dan 2.

\section{Hasil kultur urin}

Duapuluh tujuh spesimen urin (28\%) tumbuh kuman dalam media biakan. Kuman yang paling banyak ditemukan adalah Escherichia coli, 9 (33\%) spesimen. Kuman Gram negatif mendominasi hasil pemeriksaan dengan 17 (63\%) spesimen. Hasil tes kepekaan kuman pada kultur urin tertera pada Gambar 3 dan 4.

\section{Luaran}

Sebagian besar episode demam neutropenia dengan luaran sembuh, 31 episode, adalah risiko rendah. Episode demam neutropenia risiko tinggi, sebagian besar 30 episode, memiliki luaran tidak sembuh. Berdasarkan skor Rondinelli, luaran sembuh dengan risiko rendah 31 dan tinggi 12, tidak sembuh dengan risiko rendah 17 dan tinggi 30, sedangkan meninggal dengan risiko rendah 2 dan tinggi 4.

Perhitungan chi square dengan $\mathrm{p}<0,05$ hubungan

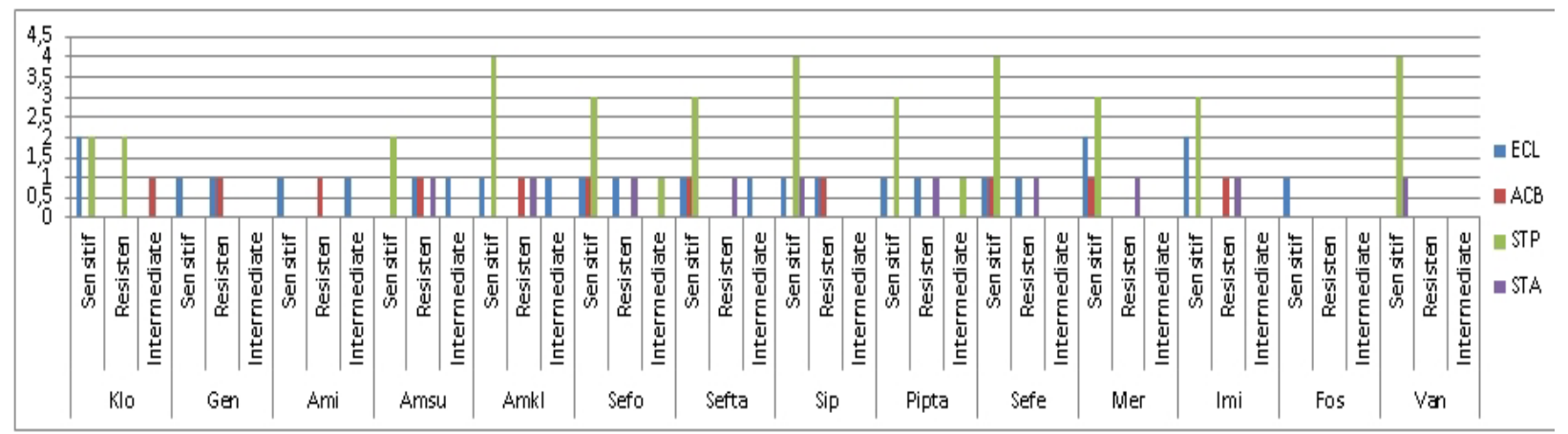

Gambar. 1. Karakteristik kepekaan kuman hasil kultur darah

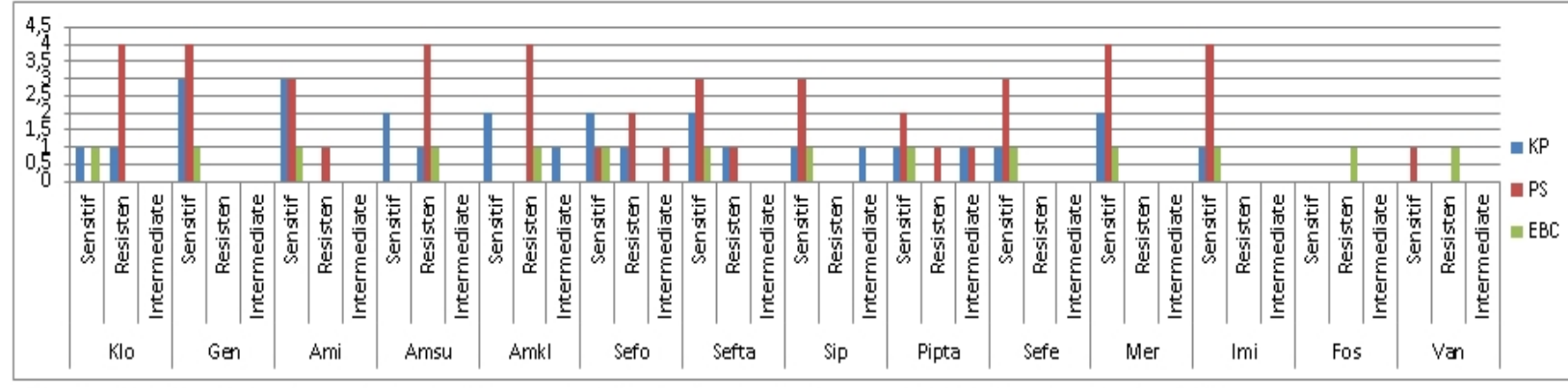

Gambar. 2. Karakteristik kepekaan kuman hasil kultur darah

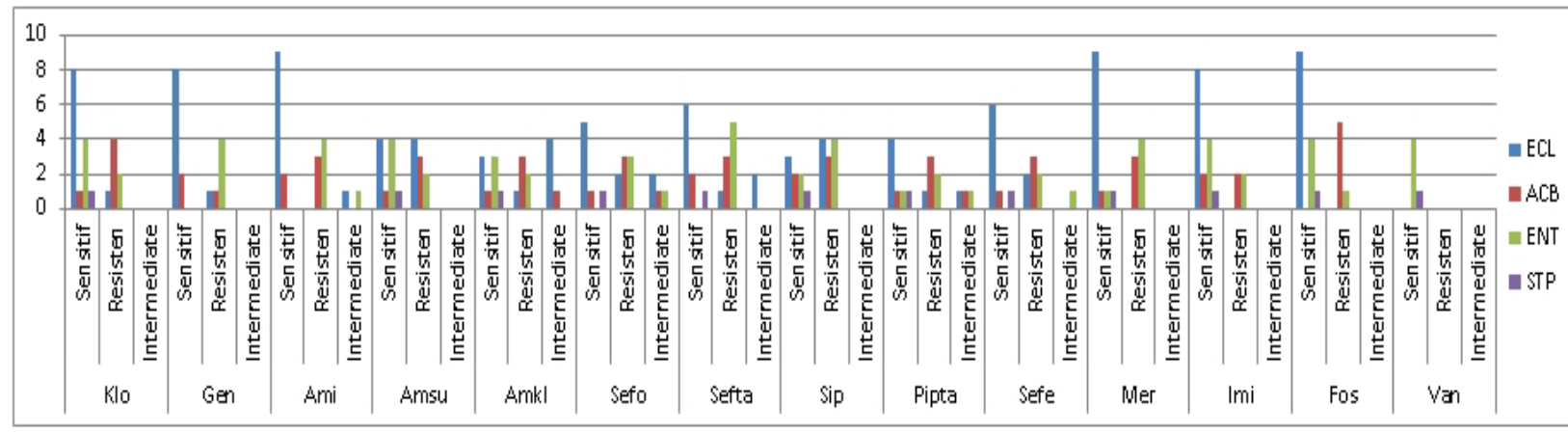

Gambar. 3. Karakteristik kepekaan kuman hasil kultur urin 


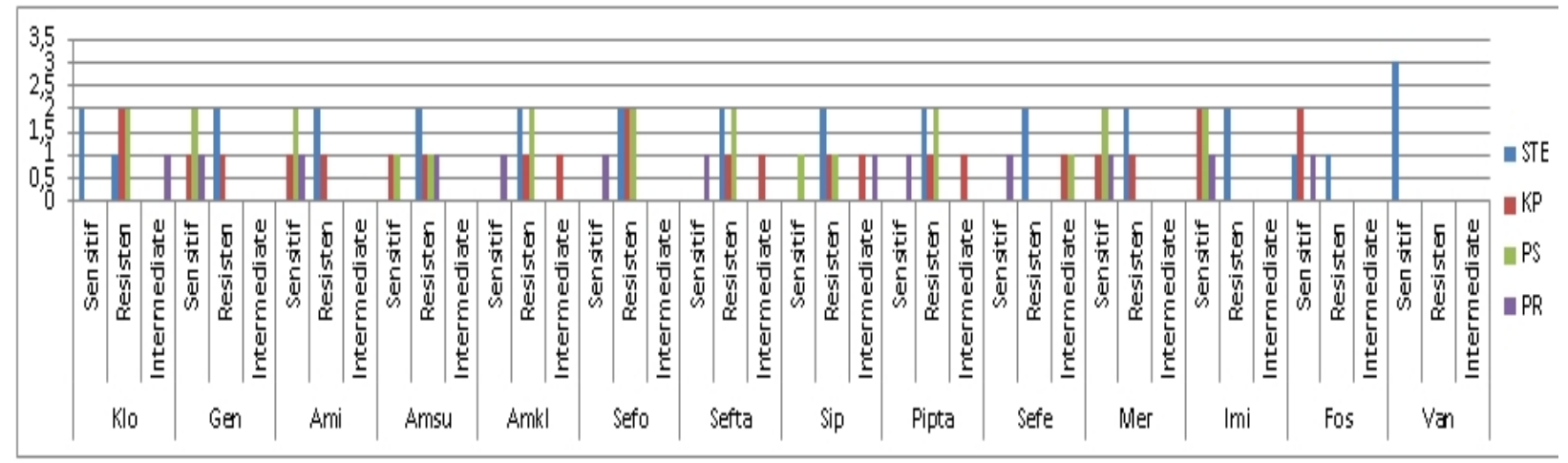

Gambar. 4. Karakteristik kepekaan kuman hasil kultur urin

hasil skor Rondinelli dan luaran sembuh dengan klasifikasi risiko rendah adalah 31 dan tinggi 12 (RR IK 95\%; 4,62; $\mathrm{p}=0,000 ; \mathrm{n}=96)$. Sebaliknya, luaran tidak sembuh dengan risiko rendah adalah 19 dan tinggi 34 (RR IK 95\%; 1,93-11,0; n=96)

\section{Pembahasan}

Limapuluh satu (53\%) episode demam neutropenia memiliki fokus infeksi saat awal didiagnosis demam neutropenia. Rondinelli $\mathrm{dkk}^{6}$ mendapatkan 38\% subjek memiliki fokus infeksi. Tingkat pemahaman pasien, edukasi pasien yang kurang, serta penanganan yang kurang tepat pada pasien dengan neutropenia meningkatkan insiden terjadinya infeksi. ${ }^{8}$ Fokus infeksi tersering ditemukan pada saluran cerna, kulit, dan saluran nafas atas. Keadaan neutropenia dan kerusakan mukosa saluran cerna akibat efek samping kemoterapi membuat saluran cerna rentan menjadi fokus infeksi pada anak dengan keganasan. ${ }^{9}$ Laporan fokus infeksi Rondinelli meliputi mukositis (24\%), saluran cerna (18), pneumonia (13\%), kulit (15\%), saluran nafas atas $10 \%$, dan saluran kemih $10 \%{ }^{6}$ Karakteristik fokus infeksi pada penelitian ini tidak jauh berbeda, saluran pencernaan $19 \%$, saluran nafas $15 \%$, infeksi kulit $13 \%$, dan infeksi telinga 3\%. Mukositis sebagai fokus infeksi tidak ditemukan karena data yang terdapat di rekam medis tidak mencantumkan hal tersebut. Rekam medis lebih sering mencantumkan diare yang dapat merupakan gejala klinis mukositis.

Penelitian ini mendapatkan 80 (84\%) spesimen steril pada pemeriksaan kultur darah. Hakim, ${ }^{11}$ dalam penelitiannya, memperoleh hasil yang tidak jauh berbeda (88\%). Pada pasien demam neutropenia, hasil kultur darah yang steril karena demam disebabkan oleh faktor non infeksi seperti keganasan atau reaksi transfusi. Infeksi oleh virus dan jamur akan menghasilkan pemeriksaan kultur darah yang steril. Hakim mendapatkan proporsi infeksi jamur dan virus berturut turut $1,2 \%$ dan $3 \%$. Faktor teknis, seperti cara pengambilan sampel, volume sampel, dan penyimpanan sampel dapat memengaruhi hasil kultur darah. ${ }^{11}$

Hasil kultur darah positif merupakan prediktor adanya infeksi berat pada demam neutropenia. Penelitian ini mendapatkan 14 episode demam neutropenia dengan kultur darah positif memiliki luaran tidak sembuh. Sepuluh spesimen dari 14 spesimen tersebut disebabkan oleh kuman Gram negatif. Secara keseluruhan, 69\% penyebab bakterimia pada demam neutropenia disebabkan oleh kuman Gram negatif.

Seluruh episode demam neutropenia risiko tinggi dengan hasil kultur darah positif memiliki luaran tidak sembuh. Pasien demam neutropenia risiko tinggi harus mendapat terapi antibotik empiris yang optimal. Sefotaksim tidak dianjurkan digunakan sebagai terapi empiris tunggal pada demam neutropenia. Sefotaksim resisten untuk Pseudomonas aeruginosa dan Klebsiella pneumoniae. Hal tersebut juga sesuai dengan laporan berkala kepekaan kuman di RSCM periode Juli - Desember 2012 yang mendapatkan sensitifitas sefotaksim terhadap Pseudomonas sp $11 \% .{ }^{12}$ Penggunaan sefotaksim sebagai terapi empiris perlu ditinjau kembali. Seftazidim tidak direkomendasikan digunakan sebagai terapi tunggal pada pasien demam neutropenia risiko tinggi karena kurang efektif terhadap bakteri patogen Gram negatif dan Streptococcus viridans. ${ }^{9}$ 
Efektifitas meropenem dan seftazidim lebih baik dibanding antibiotik yang lain. Seftazidim merupakan antibiotik pertama yang terbukti efektif sebagai antibiotik tunggal pada demam neutropenia. ${ }^{1}$ Sebaliknya, sefotaksim dan piperasilin tazobaktam sebaiknya tidak digunakan sebagai terapi empiris pada pasien demam neutropenia karena aktifitasnya yang rendah pada kuman Pseudomonas aeruginosa. Kombinasi seftazidim dan amikasin dapat digunakan sebagai antibiotik empiris demam neutropenia risiko tinggi.

Infeksi saluran kemih merupakan salah satu fokus infeksi yang sering ditemukan pada pasien demam neutropenia. Penelitian ini mendapatkan 27 episode demam neutropenia dengan hasil kultur urin positif. Tidak berbeda dengan hasil kultur darah, kuman Gram negatif menjadi penyebab terbanyak infeksi saluran kemih (63\%). Kuman terbanyak yang ditemukan adalah Escherichia coli (33\%). Departemen Patologi Klinik RSCM juga mendapatkan hasil yang hampir sama, $52(36 \%)$ dari 143 sampel urin didapatkan kuman Escherichia coli. ${ }^{12}$

Berikut adalah hasil tes kepekaan Escherichia coli pada antibiotik empiris yang digunakan, meropenem $100 \%$, amikasin $89 \%$, seftazidim $83 \%$, dan sefotaksim 67\%. Sebagai perbandingan, Departemen Patologi Klinik RSCM mendapatkan hasil kepekaan Escherichia coli sebagai berikut, meropenem $100 \%$, amikasin $83 \%$, seftazidim $51 \%$, dan sefotaksim $40 \% .{ }^{12}$ Seftazidim yang digunakan pada $51 \%$ episode demam neutropenia memiliki aktifitas yang rendah pada Enterococcus $s p$, Acinetobacter sp, dan Streptococcus $\alpha$ hemoliticus. Meropenem masih menunjukkan superioritasnya dibanding antibiotik lainnya. Penggunaan meropenem yang berlebihan harus dihindari untuk menghindari resistensi kuman terhadap antibiotik ini. Berdasarkan hasil tes kepekaan kuman kultur urin, kombinasi seftazidim dan amikasin dapat digunakan untuk meningkatkan kepekaan terhadap kuman Escherichia coli dan Acinetobacter sp. Kedua bakteri tersebut adalah penyebab tersering ISK pada penelitian ini.

Skor Rondinelli digunakan untuk memprediksi terjadinya infeksi berat pada pasien demam neutropenia. Pasien berdasarkan skor Rondinelli akan diklasifikasikan menjadi risiko rendah dan tinggi. Luaran pasien dengan episode demam neutropenia risiko rendah diharapkan lebih baik daripada risiko tinggi. Penelitian ini mendapatkan 50 episode demam neutropenia risiko rendah dan 31 memiliki luaran sembuh. Pada kelompok episode demam neutropenia risiko tinggi, hanya 12 episode demam yang memiliki luaran sembuh. Pengklasifikasian pasien demam neutropenia penting untuk pemilihan jenis antibiotik. Pemberian antibiotik yang sesuai dengan klasifikasi diharapkan dapat memperbaiki luaran.

Delapan belas (34\%) episode demam neutropenia risiko rendah memiliki luaran tidak sembuh. Proporsi ini jauh lebih kecil apabila dibandingkan pada kelompok demam neutropenia risiko tinggi (64\%). Data ini mendukung tujuan penggunaan skor Rondinelli. Skor Rondinelli dengan spesifisitas 90,5\% dalam memprediksi timbulnya komplikasi infeksi berat dapat digunakan untuk klasifikasi kasus demam neutropenia dan menentukan jenis antibiotik empiris. Penggunaan skor Rondinelli dapat digabungkan dengan pemeriksaan prokalsitonin untuk peningkatan nilai diagnostiknya. ${ }^{8}$ Pada penelitian ini, luaran episode demam neutropenia dengan keganasan didapatkan 45\% memiliki luaran sembuh, $49 \%$ memiliki luaran tidak sembuh, dan $6 \%$ meninggal dunia. Penelitian ini mempunyai keterbatasan karena pengumpulan data berupa data sekunder dan bersifat retrospektif.

\section{Kesimpulan}

Prevalensi bakterimia episode demam neutropenia pada anak dengan keganasan adalah $16(17 \%)$ episode. Prevalensi infeksi saluran kemih 27 (28\%) episode. Meropenem masih superior dibanding antibiotik yang lain. Seftazidim dapat digunakan sebagai antibiotik empiris pada demam neutropenia risiko rendah. Episode demam neutropenia risiko tinggi dapat diberikan antibiotik empiris seftazidim dan amikasin. Skor Rondinelli dapat digunakan dalam praktek seharihari untuk klasifikasi demam neutropenia risiko rendah dan risiko tinggi.

\section{Daftar pustaka}

1. Windiastuti E. Antibiotika pada demam neutropenia. Dalam: Tumbelaka AR, Trihono PP, Kurniati N, Widodo DP, penyunting. Penanganan demam pada anak secara profesional. Edisi ke-1. Jakarta: Departemen Ilmu Kesehatan Anak FKUI-RSCM; 2005.h.42-9.

2. Mendes AV, Sapolnik R, Mendonca N. New guideli- 
nes for the clinical management of febrile nutropenia and sepsis in pediatric oncology patients. J Pediatr 2007;83:554-63.

3. Kanamaru A, Tatsumi Y. Microbiological data for patients with febrile neutropenia. Clin Infect Dis 2004;39:7-10.

4. Zinner SH. Changing epidemiology of infection in patient with neutropenia and cancer:emphasis on gram positive and resistan bacteria. Clin Infect Dis 1999;29:490-4.

5. Picazo J. Management of the febrile neutropenic patient: a consensus conference. Clin Infect Dis 2004;39:1-4.

6. Rondinelli PI, Riberio KC, Camargo B, Prober CG. A proposed score for predicting severe infection complication in children wih chemotherapy-induced febrile neutropenia. J Pediatr Hematol Oncol 2006;28:66570.

7. Hidayat R. Validasi sistem skoring Rondinelli untuk mendeteksi komplikasi infeksi berat pada pasien leukemia limfoblastik akut L1 dengan demam neutropenia selama kemoterapi fase induksi [Tesis]. Jakarta: Fakultas
Kedokteran Universitas Indonesia, 2013.

8. Ramphal R. Changes in the etiology of bacteremia in febrile neutropenic patients and the susceptibilities of the currently isolated pathogens. Clin Infect Dis 2004;39:2531.

9. Hadinegoro SS. Febrile neutropenia. Dalam: Windiastuti E, Sari TT, Yuniar I, Indawati W, penyunting. Dalam: Peran dokter anak dalam diagnosis dini dan pemantauan keganasan pada anak. Jakarta: Departemen Ilmu Kesehatan Anak FKUI-RSCM;2011.h.73-83.

10. Bow EJ. Management of the febrile neutropenic cancer patient: lesson from 40 years of study. Clin Microbiol Infect 2005;11:24-9.

11. Hakim H. Etiology and clinical course of febrile neutropenia in children with cancer. J Pediatr Hematol Oncol 2009;31:623-9.

12. Loho T, Astrawinata D, Mantiri GA. Bacterial and antibiotics susceptibility profile at Cipto Mangunkusumo General Hospital July - December 2012. Jakarta: Division of Infectious Diseases Departement of Clinical Pathology, 2013. 